Additional Perspectives articles for Influenza: The Cutting Edge book collection are available at http://perspectivesinmedicine.cshlp.org/cgi/collection/influenza_the_cutting_edge.

\title{
The 1918 Influenza Pandemic and Its Legacy
}

\author{
Jeffery K. Taubenberger ${ }^{1}$ and David M. Morens ${ }^{2}$ \\ ${ }^{1}$ Viral Pathogenesis and Evolution Section, Laboratory of Infectious Diseases, National Institute of Allergy \\ and Infectious Diseases, National Institutes of Health, Bethesda, Maryland 20892, USA \\ ${ }^{2}$ Office of the Director, National Institute of Allergy and Infectious Diseases, National Institutes of Health, \\ Bethesda, Maryland 20892, USA \\ Correspondence: taubenbergerj@niaid.nih.gov
}

Just over a century ago in 1918-1919, the "Spanish" influenza pandemic appeared nearly simultaneously around the world and caused extraordinary mortality-estimated at 50-100 million fatalities - associated with unexpected clinical and epidemiological features. The pandemic's sudden appearance and high fatality rate were unprecedented, and 100 years later still serve as a stark reminder of the continual threat influenza poses. Sequencing and reconstruction of the 1918 virus have allowed scientists to answer many questions about its origin and pathogenicity, although many questions remain. Several of the unusual features of the 1918-1919 pandemic, including age-specific mortality patterns and the high frequency of severe pneumonias, are still not fully understood. The 1918 pandemic virus initiated a pandemic era still ongoing. The descendants of the 1918 virus remain today as annually circulating and evolving influenza viruses causing significant mortality each year. This review summarizes key findings and unanswered questions about this deadliest of human events.

\section{IMPACT OF THE 1918 INFLUENZA}

\begin{abstract}
A little more than 100 years ago, the world experienced a catastrophic and unprecedented natural disaster, namely, the onset of the "Spanish" influenza pandemic of 1918-1919 (Jordan 1927; Taubenberger and Morens 2006; Taubenberger et al. 2019). Herein, we briefly review what has been learned about the 1918 pandemic and how that knowledge is now helping to prevent and control influenza. The 1918 pandemic appeared in almost all inhabited places on Earth, causing, over the course of a year, symptomatic disease in approximately one-third of the world's population, with evidence that a significant percentage had been asymptomatically
\end{abstract}

or subclinically infected (Philip and Lackman 1962; Masurel 1976; Dowdle 1999; Taubenberger et al. 2001). The majority of people presenting with clinical illness in the 1918 pandemic had typical, self-limiting influenza, but a disproportionate number developed lower respiratory involvement and died of the consequences of pneumonia (Morens et al. 2008). Case-fatality ratios in the United States were $\sim 0.5 \%-1.0 \%$ (Viboud et al. 2013), but case fatality was much higher in many developing countries (Chandra et al. 2012; Chandra 2013), and in many crowded environments, from inner cities (Mamelund 2006) to military training camps set up during World War I (Chertow et al. 2015). The global mortality estimates range from 50 million to as

Editors: Gabriele Neumann and Yoshihiro Kawaoka

Additional Perspectives on Influenza: The Cutting Edge available at www.perspectivesinmedicine.org

Copyright (C) 2020 Cold Spring Harbor Laboratory Press; all rights reserved; doi: 10.1101/cshperspect.a038695

Cite this article as Cold Spring Harb Perspect Med 2020;10:a038695 
J.K. Taubenberger and D.M. Morens

high as 100 million in the first pandemic year (Johnson and Mueller 2002).

The impact of the pandemic virus-now known to be an H1N1 influenza A virus-was not, however, limited to 1918-1919. The 1918 influenza A virus became a "founder virus," initiating a "pandemic era" by evolving into progeny pandemic viruses through a number of separate genetic reassortment events (Fig. 1). Since 1918, all subsequent influenza A pandemics and seasonal epidemics have been caused by descendants of the 1918 virus (Morens et al. 2009), including the antigenically drifted seasonal descendants of the 1918 H1N1 virus, and the reassorted pandemic viruses that appeared in 1957 (H2N2), 1968 (H3N2), and 2009 (H1N1pdm). Each of these descendant pandemic viruses contained gene segments descended from the 1918 virus. Some of these gene segments drifted substantially over time, and others were eventually "updated" through genetic reassortment by influenza A virus genes derived from water fowl or, in the case of the 2009 pandemic virus, by different 1918 virus-derived gene segments that had become incorporated into newly evolving swine influenza viruses
(Garten et al. 2009). As a consequence, the 1918 virus was not just responsible for the millions of global deaths during the pandemic itself, but also for the millions of additional influenzarelated deaths that have occurred in the past century of this pandemic era. In one recent year alone (2014-2015), 710,000 Americans were hospitalized for influenza and 56,000 died (Budd et al. 2018). In other years, the toll has been higher (Thompson et al. 2003). Preliminary data suggest that the 2017-2018 influenza season may have killed 80,000 Americans (Dyer 2018).

Over the last century, the 1918 influenza virus has indelibly affected our evolving conception of pandemic influenza (Taubenberger et al. 2007); public health preparedness and future pandemic planning must always take into account the possible emergence of a future pandemic of 1918-like magnitude. Although the continuing impact of the 1918 influenza virus, in the form of continually evolving, descendant human influenza A viruses, is not lessened by the passing of more than 100 years, humans have experienced previous influenza pandemics for at least 500 years, if not longer. Major influ-

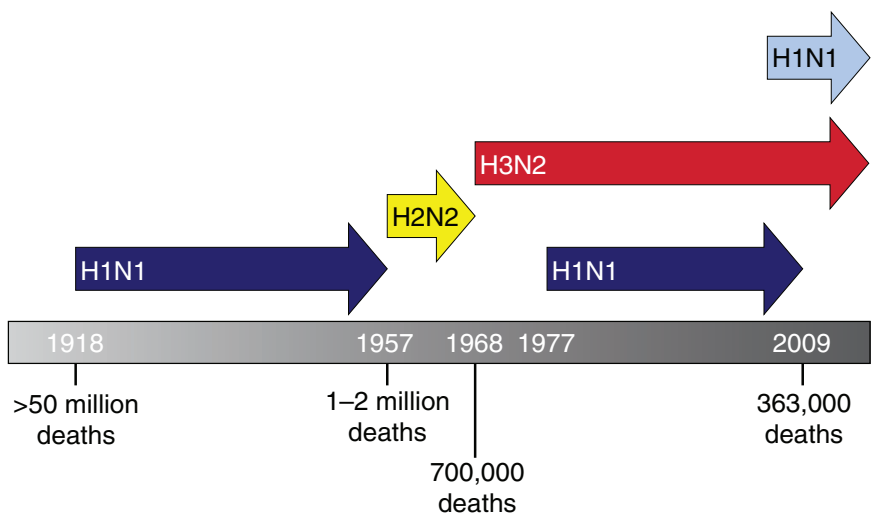

Figure 1. Influenza pandemics of the past century. The 1918 "Spanish flu" pandemic was caused by a founder H1N1 influenza A virus. The three subsequent pandemics of 1957, 1968, and 2009 resulted from descendants of the 1918 virus, which acquired one or more genes through reassortment (Morens et al. 2009). Arrows reflect the years of annual epidemics of seasonal influenza circulation that occurred after each pandemic. In 1977, pre-1957 human $\mathrm{H} 1 \mathrm{~N} 1$ viruses reemerged presumably through accidental release of an older human strain (Nakajima et al. 1978). This resulted in a 20 -year gap in H1N1 circulation as indicated by the discontinuous blue line. Consequently, human H3N2 viruses cocirculated with human 1918-lineage seasonal H1N1 viruses from 1977 until 2009, when this lineage was replaced by the novel swine-origin H1N1 2009 pandemic virus. Since 2009, H3N2 viruses have cocirculated with 2009 pandemic-lineage H1N1 viruses in humans. 
enza epidemics and pandemics have occurred since at least the Middle Ages, if not since ancient times (Taubenberger and Morens 2009; Morens et al. 2010; Morens and Taubenberger 2011). Since 1510, there appear to have been 14 influenza pandemics at irregular intervals; in the past 130 years, there were undoubted pandemics in 1889, 1918, 1957, 1968, 1977, and 2009 (Morens et al. 2009). On average, during this 509-year interval, recognized pandemics have appeared on average every 36 years.

\section{RECOVERY OF THE 1918 INFLUENZA VIRUS}

The H1N1 influenza A virus that caused the 1918 pandemic was not identified as the etiologic agent at the time (Taubenberger et al. 2007), but influenza A viruses were eventually isolated from swine in 1930 (Shope 1931) and from humans in 1933 (Smith et al. 1933). Serological data from the 1930s first suggested that the 1930s "classical" swine virus and the 1918 pandemic virus were closely related antigenically (Shope 1936); this was later supported by data from viral genetic sequence analysis and by antigenic and pathogenesis studies (Reid et al. 1999; Taubenberger et al. 2001; Memoli et al. 2009; Easterbrook et al. 2011). Studies of the subsequent pandemics, beginning with the 1957 H2N2 pandemic, eventually revealed that new pandemic viruses could arise from earlier pandemic viruses through genetic reassortment (Scholtissek et al. 1978; Kawaoka et al. 1989; Morens et al. 2009). Nevertheless, the origin and pathogenicity of the 1918 virus remained unelucidated for most of the twentieth century (Jordan 1927).

But in the modern molecular era, tiny degraded viral RNA fragments recovered from preserved lung tissues of victims of the 19181919 pandemic (Taubenberger et al. 1997, 2005; Reid et al. 1999, 2000, 2002, 2003, 2004b; Basler et al. 2001), from only a handful of the pandemic's many millions of victims, coupled with viral reverse genetics, permitted production of infectious 1918 virus that could be studied experimentally under appropriate containment (Tumpey et al. 2005a). The effort to sequence the pandemic viral genome was initiated in 1995 using formalin-fixed, paraffin-embedded 1918 influenza autopsy tissues in the collection of the National Tissue Repository of the nowdefunct Armed Forces Institute of Pathology. One case was found to be positive, and cDNA partial sequences of four of the eight viral gene segments from this case were published in 1997 (Taubenberger et al. 1997). Additional viral RNA-positive cases were identified (Reid et al. 1999), allowing the complete genome to be sequenced, an effort that took 9 more years (Taubenberger et al. 2005). An effort to identify additional 1918 influenza-RNA-positive cases was successful. Sequencing showed high levels of viral sequence identity between cases separated by thousands of miles (Reid et al. 2003; Sheng et al. 2011) and included four cases from the period of May-August 1918, before the pandemic had extended globally. These sequence data suggest that the 1918 pandemic was almost identical genetically in its near-simultaneous appearances around the globe, and that it shared many genetic features with, and was likely derived from, a wild waterfowl influenza A virus that had somehow directly or indirectly switched hosts to become a human-adapted virus. Reverse genetics for influenza viruses, developed in 1999 (Fodor et al. 1999; Neumann et al. 1999), allowed production of infectious influenza A virions containing one or more 1918 virus genes for in vitro and in vivo studies, which provided initial characterization of 1918 viral pathogenesis (Basler et al. 2001; Geiss et al. 2002; Tumpey et al. 2002, 2004, 2005a,b, 2007; Stevens et al. 2004, 2006; Glaser et al. 2005; Kash et al. 2006; Palese et al. 2006), addressing questions of host adaptation, pathogenesis, the role of the host inflammatory response, and factors associated with transmission in mammals.

\section{ORIGIN OF THE 1918 PANDEMIC H1N1 VIRUS}

It will likely not be possible to pinpoint the origin of the 1918 pandemic virus, including elucidating how, where, and when it emerged to initiate sustained human-to-human pandemic transmission. It would have been difficult or impossible, during this early prepandemic period, 
to recognize infections and fatalities that occurred beneath the background of deaths from seasonal influenza and from other prevalent respiratory agents. It would be useful to obtain genome sequences of influenza viruses from cases before May 1918, when the earliest virally confirmed fatal 1918 case occurred (Sheng et al. 2011). Such sequences would help address questions regarding the origin of the 1918 pandemic virus and understanding population immunity as it existed before the pandemic, but will not locate the viral origin.

What is the epidemiological evidence for the origin of the 1918 virus? Several locations of pandemic origin have been proposed, including Étaples, France (Oxford et al. 2002), China (Shortridge 1999), or Camp Funston/Haskell, Kansas (Barry 2004); but convincing data in support of particular points of origin are lacking. However, even without understanding where the virus first emerged, it seems to have appeared globally in just a few months (July-September 1918, perhaps slightly earlier in China and India), in an "everywhere at once" pattern rather than a "place-to-place" pattern (Oxford 2000). This suggests that the pandemic virus had already been seeded around the globe, but that fatal infections remained below the threshold of excess mortality detection, thereby epidemiologically obscuring its place of origin. Such indolent prepandemic transmission, likely beginning in or before 1918, eventually reached pandemic explosivity (and therefore recognition) only after exceeding critical excess mortality thresholds in multiple large urban populations around the globe (Morens and Taubenberger 2018). Among the first of these, in July-August 1918, were pandemic emergences identified by excess mortality, although presumably blunted by summer temperature and humidity, which are unfavorable to influenza virus spread, in China and India, and in parts of northern Europe including England, northern Germany, and Scandinavia (Jordan 1927; Andreasen et al. 2008).

Epidemiological and clinical data from the U.S. Army training camps in 1917-1918 showed three peaks of acute respiratory disease incidence before and during the 1918 pandemic
(Chertow et al. 2015). Low-incidence influenza outbreaks in December 1917 and in April 1918 were associated with case-fatality ratios fivefold lower than during the 1918 fall peak. Importantly, few of the winter 1917-spring 1918 cases were complicated by bronchopneumonia, a hallmark of the 1918 pandemic (Morens et al. 2008). These observations suggest that the winter 1917 and spring 1918 influenza-like illness peaks were largely caused by nonpandemic seasonal influenza viruses, which typically circulate throughout the winter and early spring, and did not represent early pandemic waves (Morens and Taubenberger 2009; Viboud et al. 2013).

Additional investigations using clinical, pathological, bacteriological, and virological findings from 68 fatal influenza/pneumonia patients from U.S. military training camps provided further evidence. Nine of the 68 fatal cases occurred before the September-November 1918 pandemic wave (Sheng et al. 2011), with deaths occurring between May 11 and August 8, 1918, a time period when there was no evidence of elevated influenza mortality in the United States. Interestingly, the prepandemic and pandemic peak cases were indistinguishable clinically and pathologically, as were their viral sequences. Partial hemagglutinin (HA) sequences from four of these prepandemic cases have been determined, covering the receptor-binding domain on the head of the HA molecule. These sequences match sequences from fall wave cases, and together only vary at one amino acid residue in the receptor-binding region (at site 222 of the HA1 domain). Viral antigen distribution in the respiratory bronchoalveolar tree was also not apparently different between prepandemic and pandemic peak cases, or between infections with viruses bearing these receptor-binding polymorphisms, including those with more human-like $(\alpha 2-6>\alpha 2-3$ sialic acids) and those with more avian-like receptor-binding preferences ( $\alpha 2-3>\alpha 2-6$ sialic acids) (Sheng et al. 2011; also, see below).

In an experiment performed to evaluate 1918 viral pathogenicity in mice, 7:1 chimeric 1918 influenza viruses were created in which each of the eight 1918 virus gene segments was replaced, one at a time, by the corresponding 
gene segment of a modern wild waterfowl H1N1 virus (Qi et al. 2012). In this study, seven of the 1918 7:1 chimeric viruses replicated and caused disease that was equivalent to the extreme pathogenicity of the fully reconstructed 1918 virus, including the 1918 pandemic chimeric virus with the modern waterfowl $\mathrm{H} 1 \mathrm{HA}$. Only the chimeric 1918 virus containing the waterfowl influenza PB2 gene segment was attenuated; a single amino acid change (E627K) corrected this attenuation. The E627K mutation is one of the mutational changes at the carboxy-terminal end of the influenza A virus PB2 protein often seen in nonpandemic avian-descended influenza A viruses that infect humans and mammals (Subbarao et al. 1993; Hatta et al. 2001; Taubenberger and Kash 2010; Manz et al. 2013), apparently representing an easily acquired adaptational change in these new hosts. The 1918 pandemic virus, whatever its origin, was clearly similar pathophysiologically to a wild waterfowl influenza A virus. These data, coupled with 1918 HA sequence data from early (prepandemic) 1918 cases (Sheng et al. 2011), strongly support the conclusion that the earliest circulating $1918 \mathrm{vi}-$ ruses were virtually identical to, and as inherently pathogenic as, the viruses sequenced from the main pandemic wave in the fall of 1918 .

The origin of the 1918 pandemic virus has also been investigated by studying its genome and coding sequences as compared with those of other influenza A viruses (Smith et al. 2009; Taubenberger and Kash 2010). Gene segments from the 1918 pandemic virus have a nucleotide composition and a high guanosine-cytosine content like those of influenza A viruses that (then and now) circulate in wild waterfowl, and unlike influenza A virus strains adapted to humans (Rabadan et al. 2006; Greenbaum et al. 2008; Dunham et al. 2009). This indicates that, with or without adaptation in an intermediate host, the 1918 virus was likely derived from a waterfowl influenza A virus. Phylogenetic analyses have also been used to model the origin of the 1918 virus but have generated different dates for the estimated origin of the pandemic virus (Reid et al. 2004a; Taubenberger et al. 2005; Smith et al. 2009; Worobey et al. 2014). Until pre-1918 influenza A virus sequences are recov- ered, resolving the dates of origin of the 1918 virus phylogenetically will remain challenging. It appears highly unlikely on epidemiological and biological grounds that a virus expressing the pandemic $\mathrm{H} 1 \mathrm{HA}$, with its inherent virulence, could have widely circulated in humans much before 1918.

Another epidemiological characteristic of the 1918 influenza virus was infection of both humans and pigs. Influenza was first recognized as a clinical entity in swine in the United States in the autumn of 1918 (Koen 1919), concurrent with the spread of the pandemic in humans (Dorset et al. 1922; Taubenberger et al. 2001), having apparently been transmitted from humans to pigs. This host-switch event allowed the 1918 virus to diverge into two independent viral lineages-one human, one porcine. After 1918, annual enzootics became widespread among swine populations in the U.S. Midwest, preceding Shope's 1930 isolation of the first influenza virus, A/swine/Iowa/30 (Shope 1931), 3 years before the first human isolation of a descendant of the parent 1918 virus, A/Wilson-Smith/33 (Smith et al. 1933). The two 1918 viral H1N1 lineages-one human, the other porcine-evolved and drifted at different rates until 2009. In the 2009 pandemic, the humanadapted H1N1 descendant was replaced by a different $\mathrm{H} 1 \mathrm{~N} 1$ virus that was also a 1918 viral descendant, ironically one that had been circulating enzootically in pigs. The original 1918 "classical" swine lineage virus still circulates enzootically (Nelson et al. 2015; Walia et al. 2019).

\section{INFLUENZA VIRUS PATHOGENICITY}

The 1918 viral genome has been studied for molecular features potentially associated with human adaptation (Taubenberger and Kash 2010). These include amino acid changes that have been associated with mammalian adaptation in nature and in experimental systems, such as alterations in the HA receptor-binding domain and in the viral polymerase complex. When other waterfowl-to-mammalian influenza A virus host-switch events are compared genetically; however, there is little evidence for shared adaptational mechanisms (Dunham et al. 2009). The 
$2009 \mathrm{H} 1 \mathrm{~N} 1$ pandemic virus further showed the independent and polygenic nature of individual influenza A virus host switching (Mehle and Doudna 2009; Herfst et al. 2010; Jagger et al. 2010).

The ability of an influenza A virus to infect cells of a new host is one of the most important properties associated with host-switching. Viral attachment to target respiratory epithelial cells is mediated by HA binding to receptor glycans with terminal sialic acids in different configurations with underlying sugars (e.g., $\alpha 2-3-$ and $\alpha 2-6$-linked sialic acids). The HA receptorbinding domain region was sequenced in 16 fatal 1918 autopsy cases (Sheng et al. 2011), revealing several naturally occurring viral mutations in persons who died between May 1918 (prepandemic) and February 1919 (after the pandemic peak). All such $\mathrm{H} 1$ viruses had the E187D mutation in the HA receptor-binding domain as compared with that of conserved avian $\mathrm{H} 1$ influenza A viruses. Some cases also had either a G222D or G222N mutation in the HA receptor-binding domain, and one case had a Q189R mutation. Structural analyses and in vitro binding to glycan arrays showed that the 1918 pandemic influenza virus $H A$ with a G222 had a blended $\alpha 2-3>\alpha 2-6$ sialic acidbinding specificity, whereas HA with a G222D had predominantly $\alpha 2-6$ sialic acid-binding specificity. No differences in viral antigen distribution were observed along the respiratory tract of the 1918 influenza cases with these different receptor-binding domain polymorphisms, along with no apparent differences in their clinical course or pathological findings (Sheng et al. 2011). When 1918 pandemic influenza receptor domain-variant viruses were evaluated for both viral entry and for replication in primary human bronchial epithelial airway cells in vitro, all receptor-binding variants bound to and infected airway cells comparably (Davis et al. 2016). Along with data from mouse and ferret studies (Tumpey et al. 2007; Qi et al. 2009, 2012), these observations indicate that cellular tropism of 1918 influenza viruses bearing the various HA receptor-binding domain mutations, either associated with an $\alpha 2-6$ sialic acid-binding preference or a mixed $\alpha 2-3 / \alpha 2-6$ sialic acid-binding preference, have no apparent impact on viral infectivity. In an experimental ferret study, 1918 virus variants with blended $\alpha 2-3 / \alpha 2-6$ sialic acid-binding specificity were, however, less transmissible (one of three contact animals) than 1918 viruses with an $\alpha 2-6$ sialic acid-binding specificity (three of three contact animals), although the relevance of these data for human infections remains unclear (Tumpey et al. 2007).

Mutations in the carboxy-terminal region of the polymerase protein $\mathrm{PB} 2$ have been associated with influenza A virus host-switching, especially E627K (Subbarao et al. 1993). The E627K mutation was observed in the 1918 virus and also in some naturally occurring avian influenza A virus infections of humans, and has been identified as an important host-adaptational factor in experimental mammalian studies (Subbarao et al. 1993; Hatta et al. 2001; Watanabe et al. 2009; Ma et al. 2011; Qi et al. 2012). The 2009 pandemic virus PB2, however, did not possess any of the previously observed key changes at residues 627, 701, or 702 in PB2 (Garten et al. 2009), although possessing novel changes at PB2 residues 590-591 (Mehle and Doudna 2009; Yamada et al. 2010). Collectively, these observations suggest that adaptive mutations in waterfowl influenza A virus hostswitching events, including those associated with emergence of a pandemic virus like the 1918 virus, might be unique to specific viruses and their new hosts, and that there may be multiple paths by which mutations and genetic epistasis can lead to novel host adaptation.

As noted, viral virulence factors that contribute to pathogenicity of the 1918 virus have also been investigated in experimental animal infections using chimeric influenza viruses containing one or more gene segments from the 1918 virus. Viral chimeras expressing the 1918 pandemic $\mathrm{H} 1 \mathrm{HA}$ alone on the backbone of seasonal $\mathrm{H} 1 \mathrm{~N} 1$ or $\mathrm{H} 3 \mathrm{~N} 2$ human influenza viruses (Kobasa et al. 2004; Qi et al. 2009, 2011) led to enhanced pathology in the murine respiratory tract, characterized by prominent infiltration of alveolar neutrophils and macrophages into lung air spaces, and virus replication in alveolar epithelial cells, similar to that induced by the fully reconstructed 1918 virus (Qi et al. 2012). As 
discussed above, a chimeric 1918 virus in which the $1918 \mathrm{H} 1 \mathrm{HA}$ gene had been replaced by a modern wild waterfowl-derived H1 HA gene was equally pathogenic in experimental animals as the 1918 virus itself, producing a pattern of disease and pathology not different from that caused by the 1918 virus (Qi et al. 2012). Viruses capable of replicating in mammals that express a wild waterfowl H1 HA are therefore inherently pathogenic for mammals, likely including humans. The influenza A virus polymerase genes have also been shown to contain virulence factors in animal models. In other studies, chimeric influenza A viruses encoding the four ribonucleoprotein gene segments of the 1918 virus (PB2, PB1, PA, and NP), in the context of the remaining genes from seasonal influenza viruses, also showed enhanced pathogenicity in mice and ferrets (Watanabe et al. 2009; Jagger et al. 2010).

The severe pathogenicity associated with the 1918 pandemic H1 HA seems to be shared with other wild avian H1 HAs (Koçer et al. 2012; Qi et al. 2014; Watanabe et al. 2014). Consequently, a major determinant of 1918 pandemic mortality was incorporation into the viral genome of an inherently pathogenic $\mathrm{H} 1$ gene that preexisted in nature. Avian influenza A viruses expressing H1 subtype HAs that are similar to those that existed in 1918 still circulate in nature today. Thus, an avian $\mathrm{H} 1$ virus is presumably capable of reemerging as a genetic component of a future pandemic virus.

This result brings into question whether the 16 HAs found in wild waterfowl in nature exist on a spectrum of inherent pathogenic potential for humans, and whether similarly pathogenic HAs other than H1 may exist in nature. Experimental studies have shown that, as was true for the $1918 \mathrm{H} 1$ virus (Tumpey et al. 2005a; Perrone et al. 2008; Qi et al. 2012; Kash et al. 2014), modern wild waterfowl chimeric influenza A viruses expressing $\mathrm{H} 1, \mathrm{H} 6, \mathrm{H} 7, \mathrm{H} 10$, and $\mathrm{H} 15$ subtype HAs also induce enhanced pathogenicity in mice and more rapid cytopathicity in human bronchial airway epithelial cells. Further, the pathology caused by infection with these $\mathrm{H} 1, \mathrm{H} 6, \mathrm{H} 7, \mathrm{H} 10$, and $\mathrm{H} 15$ viruses is characterized by pronounced neutrophil infiltration into lung air spaces, a principle feature of the patho- logical findings in animals infected with the 1918 virus. In addition, there is higher host gene expression relating to recruitment and activation of neutrophils genes and genes associated with increased cytopathicity and robust activation of host inflammatory and cell death responses (Kash et al. 2006; Kobasa et al. 2007). The pathobiology observed included neutrophilic alveolitis, respiratory tissue damage secondary to reactive oxygen species, and lung cell death, all consistent with the typical features of 1918 autopsy studies (Kash et al. 2014; Qi et al. 2014; Walters et al. 2016).

Additionally, experimental nonhuman primate infections with the 1918 virus showed that within virus-infected airway epithelial cells (Kobasa et al. 2007), proinflammatory responses (including elevated expression of cytokines, chemokines, and acute phase response reactants, along with suppression of antiviral responses) led to potent activation of immune cells, cell death responses, oxidative damage, and enhanced disease severity (Kash et al. 2014). Transcriptomic analysis of a 1918 pandemic autopsy sample (Xiao et al. 2013) showed a marked concordance with the transcriptomic patterns of experimentally infected mice (Kash et al. 2006) and cynomolgus macaques (Kobasa et al. 2007). Of potential importance for understanding and treating severe influenza disease, mice infected with a lethal dose of the 1918 virus who were subsequently treated with a catalytic catalase/ superoxide dismutase mimetic drug had reduced alveolar epithelial cell damage caused by reactive oxygen species, less severe lung pathology, greater activation of tissue repair responses, and enhanced survival (Kash et al. 2014).

Collectively, these observations indicate that pandemic viruses, like the 1918 virus, that potentially emerge from waterfowl influenza A viruses can bring with them preexisting virulence determinants of pathogenicity for humans, expressed as marked cytopathicity linked with destructive immune responses. This suggests that influenza A viruses with HAs other than those we have already encountered in pandemic viruses in the past century $(\mathrm{H} 1, \mathrm{H} 2$, and $\mathrm{H} 3)$ may potentially emerge to cause disease severity comparable to that of the 1918 virus. 
J.K. Taubenberger and D.M. Morens

Although the 1918 influenza virus caused tens of millions of deaths worldwide, the vast majority of those who were infected had a typical self-limited illness indistinguishable from clinical influenza seen today, and they promptly recovered. However, influenza infections can be complicated by hemorrhagic bronchitis, diffuse alveolar damage (DAD) in the lung, and viral and bacterial pneumonia (Kuiken and Taubenberger 2008; Taubenberger and Morens 2008). Progression to severe disease is a multifactorial process involving viral, host, and bacterial factors (Taubenberger and Kash 2010).

Histopathological features of primary influenza viral pneumonia, including $\mathrm{DAD}$, pulmonary edema, and alveolar hemorrhage, were observed in autopsy studies of the 1918 pandemic (Fig. 2) as well as autopsy studies of subsequent pandemics (LeCount 1919a,b; Mulder and Hers 1972; Kuiken and Taubenberger 2008; Taubenberger and Morens 2008; Gill et al. 2010). Findings in fatal 1918 pandemic cases, however, were also characterized by widespread pulmonary vascular thrombus formation and prominent infiltration of lung tissue by neutrophils (LeCount 1919a,b; Winternitz et al. 1920; Taubenberger and Morens 2008; Sheng et al. 2011; Walters et al. 2016). Areas of lung showing these features in 1918 autopsies are usually admixed with areas of tissue repair and other areas showing features of secondary bacterial bronchopneumonia (Kuiken and Taubenberger 2008; Taubenberger and Morens 2008; Sheng et al. 2011). This asynchronous pathology associated with primary damage caused by the virus, subsequent tissue repair by the host, and secondary bacterial pneumonia, is also observed in experimental animal models of influenza and bacterial coinfection (Kash et al. 2011; Chertow et al. 2016; Walters et al. 2016). It should be emphasized that, although fulminant fatal primary influenza viral pneumonias have been documented, the vast majority of severe influenza-associated pneumonias in 1918 were associated with secondary bacterial infections (Morens et al. 2008; Chertow and Memoli 2013).

The 1918 pandemic manifested another unusual epidemiological determinant of severity- the unprecedented age-specific mortality pattern, in which young adults were at a high risk of dying, a feature not observed in influenza outbreaks before or since (Jordan 1927; Taubenberger and Morens 2006; Viboud et al. 2013; Morens and Taubenberger 2018). Influenza age-specific mortality is normally "U-shaped," with high mortality in the very young and the very old, and with low mortality in healthy persons in between these ages. The 1918 mortality curve, however, was "W-shaped," with an additional mortality peak in persons 20-40 years old (Fig. 3; Morens and Taubenberger 2018), and an increased (although to a lesser degree than expected) mortality in elderly populations. The decreased mortality in the elderly could be attributed to nineteenth century exposure to then-prevalent influenza A viruses either containing an $\mathrm{H} 1 \mathrm{HA}$ or an $\mathrm{N} 1$ neuraminidase (NA), or to other conserved antigens in common with the 1918 virus (Taubenberger and Morens 2006; Viboud et al. 2013). Although the 1918 virus was pathogenic for persons of all ages, the disproportionate increase in frequency of secondary bacterial pneumonias in healthy young adults might be an additional manifestation of viral pathogenicity related to differential host immune responses (Xiao et al. 2013; Kash et al. 2014; Chertow et al. 2015; Kash and Taubenberger 2015; Walters et al. 2016).

Almost all of millions of fatal cases worldwide during the 1918 pandemic were associated with secondary bacterial infections, primarily with Gram-positive bacteria (Fig. 2; Morens et al. 2008). These secondary infections in 1918-1919 were most frequently associated with the pneumopathogens Streptococcus pneumoniae, Streptococcus pyogenes, and Staphylococcus aureus (Morens et al. 2008). Had it not been for secondary bacterial pneumonias caused by these and other pneumopathogens, the 1918 pandemic likely would have been associated with a far lower mortality (Chertow et al. 2015). Increased incidence of secondary bacterial pneumonias in persons with influenza may be thus considered an intrinsic property of viral pathogenicity, and this is likely to be the case for other pathogenic influenza viruses. 

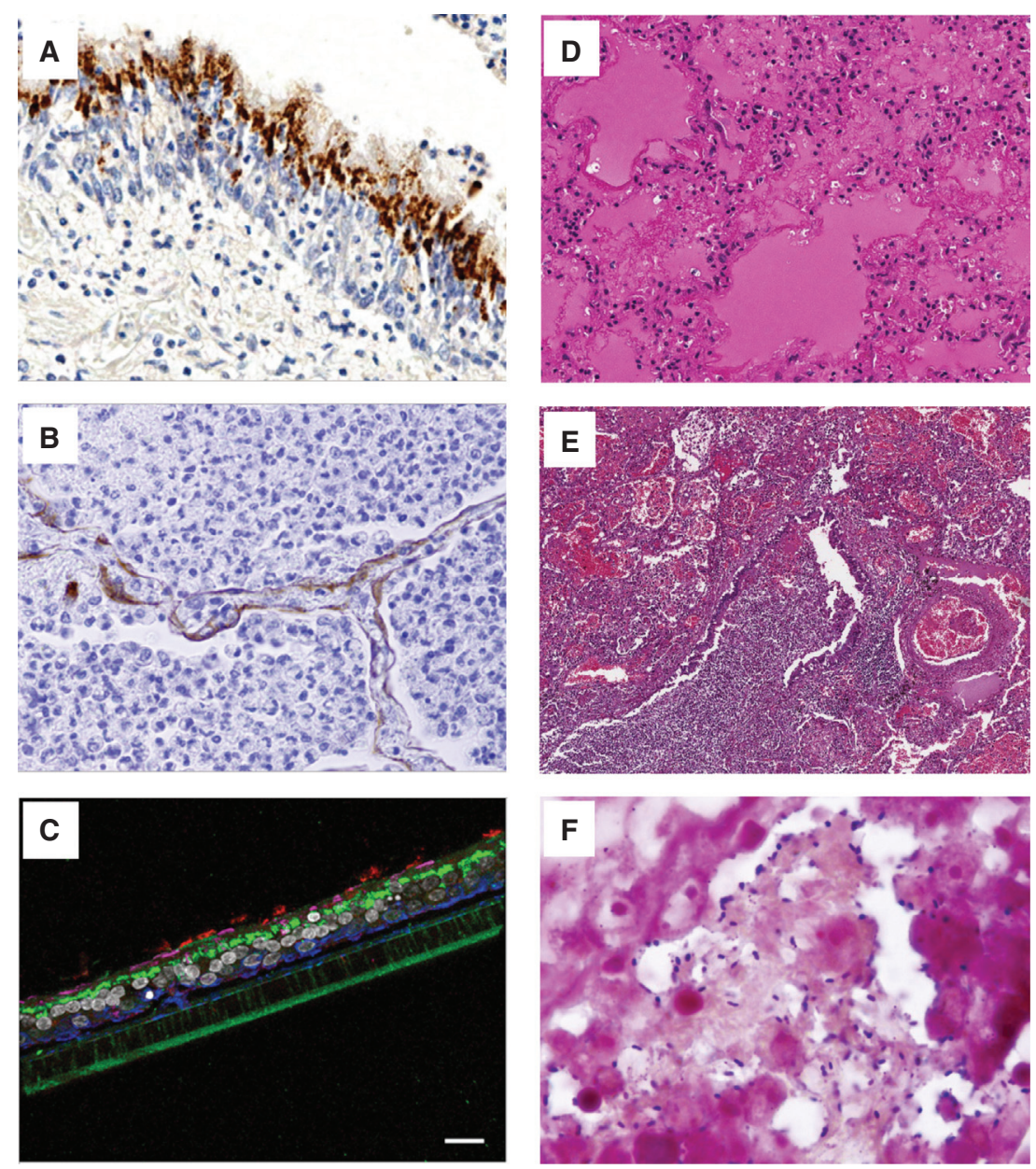

Figure 2. Pathologic features of the 1918 virus. (A) 1918 influenza viral antigens were observed throughout the entire respiratory tract in autopsy tissues of 1918 victims, including epithelial cells in the tracheobronchial tree (the brown stain on a light blue background shows an immunohistochemical stain for influenza viral antigens). $(B)$ Influenza viral antigens were similarly seen in the alveolar lining cells and alveolar macrophages of the lung. (C) 1918 HA sequences from different human autopsy specimens contained polymorphisms that affect receptorbinding specificity. No differences were observed, however, in the distribution of viral antigen in autopsy tissues. This is supported by in vitro modeling to assess binding to human bronchial airway epithelial cells as imaged by confocal microscopy. The pseudocolors are influenza viral antigen (green), goblet cells (magenta), ciliated cells (red), basal cells (blue), and nuclei (gray). Scale bar, $20 \mu \mathrm{m}$. (D) Section of lung showing diffuse alveolar damage (DAD) with hyaline membranes lining alveoli. The alveolar airspaces contain edema fluid, strands of fibrin, desquamated epithelial cells, and inflammatory cells. Original magnification, 400×. (E) Section of lung with acute pneumonia, showing a bacterial bronchopneumonia pattern consisting of necrotizing bronchitis and bronchiolitis, and massive infiltration of neutrophils into the airspaces of surrounding alveoli. Original magnification, 100×. (F) Tissue Gram stain of a fatal 1918 influenza pneumonia case. Gram-positive cocci morphologically compatible with Streptococcus pneumoniae. Original magnification, $1000 \times . A, B$, and $D-F$ represent histologic findings from 1918 autopsy cases (Reid et al. 2003). $C$ shows a confocal image produced using methods as described in Walters et al. (2016). 
J.K. Taubenberger and D.M. Morens

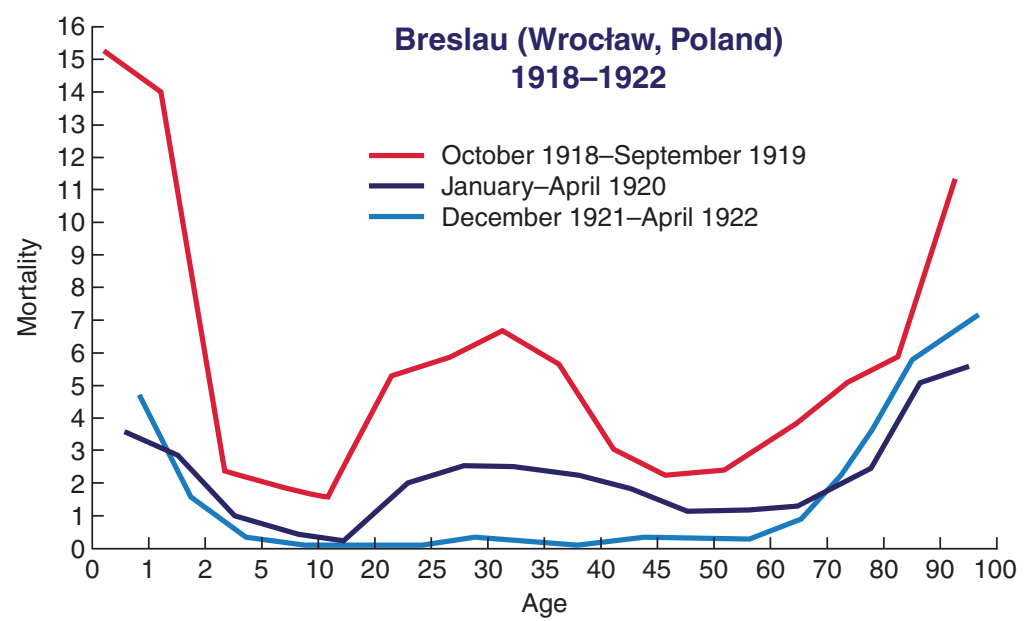

Figure 3. Age-specific influenza mortality (1918-1922). The 1918 Spanish flu pandemic appeared in Breslau (now Wrocław, Poland) in October 1918, causing high mortality. The "W-shaped" age-specific mortality pattern shown here was seen worldwide. Influenza age-specific mortality is usually "U-shaped" with higher mortality in infants and the elderly. A third peak of mortality in young adults (peaking at about age 27) was uniquely associated with the 1918 pandemic. Pandemic recurrences 15 and 26 months later were, however, associated with lower overall mortality and the virtual disappearance by 1922 of mortality in young adults (created from data in Lubinski 1923).

It remains unresolved whether viral-bacterial copathogenesis is a 1918 virus-specific property or a byproduct of other aspects of HAassociated pathogenicity such as cytopathicity or host immune activation. In a murine coinfection model of the 1918 virus and S. pneumoniae (Walters et al. 2016), secondary bacterial infection was associated with increased early bacterial replication, increased neutrophils activation, and platelet aggregation leading to frequent small vessel thrombi. Altered host immune responses to coinfection greatly enhanced lung histopathology and shortened survival. Lung pathology showed alveolar airspaces with numerous infiltrating neutrophils and macrophages, extensive acute suppurative pleuritis, widespread necrotizing bronchiolitis, and abundant fibrinous thrombi in pulmonary veins, venules, and capillaries (Walters et al. 2016).

In coinfected animals, neutrophilic infiltrates also expressed greater levels of myeloperoxidase and neutrophil elastase and increased extracellular deposition of neutrophil elastase along the vascular endothelium on alveolar and bronchiolar epithelia. 1918 virus and $S$. pneumoniae-coinfected mice also showed prominent staining for tissue factor throughout the lungs. A unique gross pathological feature of mice infected with the 1918 virus and S. pneumoniae was the presence of extensive fibrinous pleuritis, with fusion of the lungs to the chest wall and diaphragm, as was seen during the 1918 pandemic (Winternitz et al. 1920).

These experimental observations are consistent with findings from 1918 autopsy cases positive for both the influenza virus and $S$. pneumoniae, including marked expression of tissue factor in monocytes, macrophages, neutrophils, and epithelial cells, and abundant thrombi in small blood vessels (LeCount 1919a; Walters et al. 2016). Coinfection-induced pulmonary thrombosis likely exacerbated vascular leak and alveolar edema, limiting compensatory ventilation responses and contributing to severe hypoxia and death (French 1920).

\section{FUTURE OUTLOOK}

For centuries before 1918, influenza was a significant public health concern, and now, 100 years after the great pandemic, it remains a major problem, both in terms of unpredictable 
pandemics and annual seasonal epidemic recurrences of variable severity. History strongly supports that there will be future influenza pandemics, but despite a century of advancement in understanding about the pathobiology of influenza, it is still not possible to predict when and where the next pandemics will appear, what viral subtypes they will be caused by, or what pathogenic properties they will show (Morens et al. 2013a,b; Taubenberger and Morens 2013). Improved influenza virus surveillance, particularly at the animal-human interface, is crucial, but we currently do not possess the knowledge to identify prepandemic zoonotic viruses before their emergence in a pandemic.

Do all influenza viruses, including poultryadapted viruses, have the potential to acquire host adaptive mutations that lead to pandemicity (Morens et al. 2012), or is such evolution prevented by structural or functional evolutionary constraints associated with adaptation to the prior host? Among the 16 influenza A virus HAs and nine NAs known to circulate enzootically in wild waterfowl, just three of the 144 possible subtype combinations-H1N1, H2N2, and H3N2-have been observed in any humanadapted or pandemic influenza A virus since 1918. An analogous situation can be observed with waterfowl influenza A viruses that have adapted to other mammalian hosts including horses (H3N8 and H7N7) and dogs (H3N2 and H3N8) (Morens and Taubenberger 2010). Such HA and NA subtype restriction is puzzling because, for example, $\mathrm{H} 1$ and $\mathrm{H} 2$ are uncommonly found in wild waterfowl, whereas more common waterfowl subtypes, such as $\mathrm{H} 4$ and H6, have never been observed in human- or mammalian-adapted viruses. Are there biological but as yet unelucidated restraints on the ability of wild waterfowl viruses to become pandemic viruses? Looking backward to the century before 1918, epidemiological and archaeserological evidence is consistent with the speculative possibility that pandemics between the 1830s and 1889 may, like those of the past century, have only expressed $\mathrm{H} 1, \mathrm{H} 2$, or $\mathrm{H} 3 \mathrm{HA}$ subtypes.

Even with our current armamentarium of antibiotics, of influenza and bacterial vaccines, of antiviral drugs, advanced intensive care treatment, and nonpharmaceutical interventions (Vukotich et al. 2010), we still face major morbidity and mortality from influenza. One key lesson from the devastating 1918 pandemic is the need to produce better antiviral drugs and prophylactic and therapeutic monoclonal antibody therapies (Hayden 2013; Crowe 2017). We also need effective vaccines against multiple bacterial pneumopathogens, especially $S$. aureus (Fowler and Proctor 2014) and S. pyogenes (Ozberk et al. 2018) and, most crucially, effective broadly protective "universal" influenza vaccines to prevent or at least mitigate the impact of future pandemics and to prevent deaths from seasonal influenza in the periods between pandemics. Vaccines that confer long-term, broad immune responses against all influenza viruses, and especially against viruses with the most pathogenic HAs found in nature, would significantly enhance public health preparedness (Nabel and Fauci 2010; Park and Taubenberger 2016; Krammer et al. 2017; Erbelding et al. 2018).

For more than 100 years, the 1918 pandemic has served as a critical benchmark for the public health importance of influenza. The fields of microbiology, immunology, vaccinology, and epidemiology continue to use insights garnered from tiny, degraded RNA fragments from the 1918 pandemic virus. It is our hope that by a better understanding of the now century-old 1918 pandemic, we can better prepare for the future. Data obtained from the 1918 virus and its genome continue to inform clinical and public health preparedness decisions. The past century of revealing the mysteries of the 1918 virus has been rewarding, but we hope that even greater insights lie ahead. The challenges of influenza remain daunting but overcoming them remains an urgent public health necessity.

\section{ACKNOWLEDGMENTS}

This work was funded by the intramural research program of the National Institute of $\mathrm{Al}-$ lergy and Infectious Diseases.

This article has been made freely available online courtesy of TAUNS Laboratories. 
J.K. Taubenberger and D.M. Morens

\section{REFERENCES}

Andreasen V, Viboud C, Simonsen L. 2008. Epidemiologic characterization of the 1918 influenza pandemic summer wave in Copenhagen: implications for pandemic control strategies. J Infect Dis 197: 270-278. doi:10.1086/524065

Barry JM. 2004. The site of origin of the 1918 influenza pandemic and its public health implications. J Transl Med 2: 3. doi:10.1186/1479-5876-2-3

Basler CF, Reid AH, Dybing JK, Janczewski TA, Fanning TG, Zheng H, Salvatore M, Perdue ML, Swayne DE, GarcíaSastre A, et al. 2001. Sequence of the 1918 pandemic influenza virus nonstructural gene (NS) segment and characterization of recombinant viruses bearing the 1918 NS genes. Proc Natl Acad Sci 98: 2746-2751. doi:10.1073/pnas.031575198

Budd AP, Wentworth DE, Blanton L, Elal AIA, Alabi N, Barnes J, Brammer L, Burns E, Cummings CN, Davis T, et al. 2018. Update: influenza activity-United States, October 1, 2017-February 3, 2018. MMWR Morb Mortal Wkly Rep 67: 169-179. doi:10.15585/mmwr.mm6706al

Chandra S. 2013. Mortality from the influenza pandemic of 1918-19 in Indonesia. Popul Stud (Camb) 67: 185-193. doi:10.1080/00324728.2012.754486

Chandra S, Kuljanin G, Wray J. 2012. Mortality from the influenza pandemic of 1918-1919: the case of India. Demography 49: 857-865. doi:10.1007/s13524-012-0116-x

Chertow DS, Memoli MJ. 2013. Bacterial coinfection in influenza: a grand rounds review. JAMA 309: 275-282. doi:10.1001/jama.2012.194139

Chertow DS, Cai R, Sun J, Grantham J, Taubenberger JK, Morens DM. 2015. Influenza circulation in United States army training camps before and during the 1918 influenza pandemic: clues to early detection of pandemic viral emergence. Open Forum Infect Dis 2: ofv021. doi:10.1093/ ofid/ofv021

Chertow DS, Kindrachuk J, Sheng ZM, Pujanauski LM, Cooper K, Nogee D, Claire MS, Solomon J, Perry D, Sayre P, et al. 2016. Influenza A and methicillin-resistant Staphylococcus aureus co-infection in rhesus macaques-a model of severe pneumonia. Antiviral Res 129: 120-129. doi:10 .1016/j.antiviral.2016.02.013

Crowe JE Jr. 2017. Principles of broad and potent antiviral human antibodies: insights for vaccine design. Cell Host Microbe 22: 193-206. doi:10.1016/j.chom.2017.07.013

Davis AS, Chertow DS, Kindrachuk J, Qi L, Schwartzman LM, Suzich J, Alsaaty S, Logun C, Shelhamer JH, Taubenberger JK. 2016. 1918 Influenza receptor binding domain variants bind and replicate in primary human airway cells regardless of receptor specificity. Virology 493: 238-246. doi:10.1016/j.virol.2016.03.025

Dorset M, McBryde CN, Niles WB. 1922. Remarks on hog flu. J Am Vet Med Assoc 62: 162-171.

Dowdle WR. 1999. Influenza A virus recycling revisited. Bull World Health Organ 77: 820-828.

Dunham EJ, Dugan VG, Kaser EK, Perkins SE, Brown IH, Holmes EC, Taubenberger JK. 2009. Different evolutionary trajectories of European avian-like and classical swine H1N1 influenza A viruses. J Virol 83: 5485-5494. doi:10 $.1128 /$ JVI.02565-08
Dyer O. 2018. US had record flu deaths last year, says CDC. BMJ 363: k4136. doi:10.1136/bmj.k4136

Easterbrook JD, Kash JC, Sheng ZM, Qi L, Gao J, Kilbourne ED, Eichelberger MC, Taubenberger JK. 2011. Immunization with 1976 swine H1N1- or 2009 pandemic H1N1inactivated vaccines protects mice from a lethal 1918 influenza infection. Influenza Other Respir Viruses 5: 198 205. doi:10.1111/j.1750-2659.2010.00191.x

Erbelding EJ, Post DJ, Stemmy EJ, Roberts PC, Augustine AD, Ferguson S, Paules CI, Graham BS, Fauci AS. 2018. A universal influenza vaccine: the strategic plan for the $\mathrm{Na}$ tional Institute of Allergy and Infectious Diseases. J Infect Dis 218: 347-354. doi:10.1093/infdis/jiy103

Fodor E, Devenish L, Engelhardt OG, Palese P, Brownlee GG, García-Sastre A. 1999. Rescue of influenza A virus from recombinant DNA. J Virol 73: 9679-9682.

Fowler FV Jr, Proctor RA. 2014. Where does a Staphylococcus aureus vaccine stand? Clin Microbiol Infect 20: 66-75. doi:10.1111/1469-0691.12570

French H. 1920. Reports on public health and medical subjects, Vol. 4, pp. 66-109. Ministry of Health, London.

Garten RJ, Davis CT, Russell CA, Shu B, Lindstrom S, Balish A, Sessions WM, Xu X, Skepner E, Deyde V, et al. 2009. Antigenic and genetic characteristics of swine-origin $2009 \mathrm{~A}(\mathrm{H} 1 \mathrm{~N} 1)$ influenza viruses circulating in humans. Science 325: 197-201. doi:10.1126/science.1176225

Geiss GK, Salvatore M, Tumpey TM, Carter VS, Wang X, Basler CF, Taubenberger JK, Bumgarner RE, Palese P, Katze MG, et al. 2002. Cellular transcriptional profiling in influenza A virus-infected lung epithelial cells: the role of the nonstructural NS1 protein in the evasion of the host innate defense and its potential contribution to pandemic influenza. Proc Natl Acad Sci 99: 10736-10741. doi:10 $.1073 /$ pnas.112338099

Gill JR, Sheng ZM, Ely SF, Guinee DG, Beasley MB, Suh J, Deshpande C, Mollura DJ, Morens DM, Bray M, et al. 2010. Pulmonary pathologic findings of fatal 2009 pandemic influenza A/H1N1 viral infections. Arch Pathol Lab Med 134: 235-243.

Glaser L, Stevens J, Zamarin D, Wilson IA, García-Sastre A, Tumpey TM, Basler CF, Taubenberger JK, Palese P. 2005. A single amino acid substitution in 1918 influenza virus hemagglutinin changes receptor binding specificity. $J \mathrm{Vi}$ rol 79: 11533-11536. doi:10.1128/JVI.79.17.11533-11536 .2005

Greenbaum BD, Levine AJ, Bhanot G, Rabadan R. 2008 Patterns of evolution and host gene mimicry in influenza and other RNA viruses. PLoS Pathog 4: e1000079. doi:10 $.1371 /$ journal.ppat.1000079

Hatta M, Gao P, Halfmann P, Kawaoka Y. 2001. Molecular basis for high virulence of Hong Kong H5N1 influenza A viruses. Science 293: 1840-1842. doi:10.1126/science .1062882

Hayden FG. 2013. Newer influenza antivirals, biotherapeutics and combinations. Influenza Other Respir Viruses 7: 63-75. doi:10.1111/irv.12045

Herfst S, Chutinimitkul S, Ye J, de Wit E, Munster VJ, Schrauwen EJ, Bestebroer TM, Jonges M, Meijer A, Koopmans $\mathrm{M}$, et al. 2010. Introduction of virulence markers in PB2 of pandemic swine-origin influenza virus does not result in enhanced virulence or transmission. J Virol 84: 3752-3758. doi:10.1128/JVI.02634-09 
Jagger BW, Memoli MJ, Sheng ZM, Qi L, Hrabal RJ, Allen GL, Dugan VG, Wang R, Digard P, Kash JC, et al. 2010. The PB2-E627 K mutation attenuates viruses containing the $2009 \mathrm{H} 1 \mathrm{~N} 1$ influenza pandemic polymerase. MBio 1: e00067. doi:10.1128/mBio.00067-10

Johnson NP, Mueller J. 2002. Updating the accounts: global mortality of the 1918-1920 "Spanish" influenza pandemic. Bull Hist Med 76: 105-115. doi:10.1353/bhm.2002 .0022

Jordan EO. 1927. Epidemic influenza: a survey. American Medical Association, Chicago.

Kash JC, Taubenberger JK. 2015. The role of viral, host, and secondary bacterial factors in influenza pathogenesis. Am J Pathol 185: 1528-1536. doi:10.1016/j.ajpath.2014.08 .030

Kash JC, Tumpey TM, Proll SC, Carter V, Perwitasari O, Thomas MJ, Basler CF, Palese P, Taubenberger JK, García-Sastre A, et al. 2006. Genomic analysis of increased host immune and cell death responses induced by 1918 influenza virus. Nature 443: 578-581. doi:10.1038/na ture05181

Kash JC, Walters KA, Davis AS, Sandouk A, Schwartzman LM, Jagger BW, Chertow DS, Li Q, Kuestner RE, Ozinsky A, et al. 2011. Lethal synergism of 2009 pandemic H1N1 influenza virus and Streptococcus pneumoniae coinfection is associated with loss of murine lung repair responses. $m$ Bio 2: e00172-11.

Kash JC, Xiao Y, Davis AS, Walters KA, Chertow DS, Easterbrook JD, Dunfee RL, Sandouk A, Jagger BW, Schwartzman LM, et al. 2014. Treatment with the reactive oxygen species scavenger EUK-207 reduces lung damage and increases survival during 1918 influenza virus infection in mice. Free Radic Biol Med 67: 235-247. doi:10 .1016/j.freeradbiomed.2013.10.014

Kawaoka Y, Krauss S, Webster RG. 1989. Avian-to-human transmission of the PB1 gene of influenza A viruses in the 1957 and 1968 pandemics. J Virol 63: 4603-4608.

Kobasa D, Takada A, Shinya K, Hatta M, Halfmann P, Theriault S, Suzuki H, Nishimura H, Mitamura K, Sugaya N, et al. 2004. Enhanced virulence of influenza A viruses with the haemagglutinin of the 1918 pandemic virus. Nature 431: 703-707. doi:10.1038/nature02951

Kobasa D, Jones SM, Shinya K, Kash JC, Copps J, Ebihara H, Hatta Y, Kim JH, Halfmann P, Hatta M, et al. 2007. Aberrant innate immune response in lethal infection of macaques with the 1918 influenza virus. Nature 445: 319323. doi:10.1038/nature05495

Koçer ZA, Krauss S, Stallknecht DE, Rehg JE, Webster RG. 2012. The potential of avian H1N1 influenza A viruses to replicate and cause disease in mammalian models. PLoS ONE 7: e41609. doi:10.1371/journal.pone.0041609

Koen J. 1919. A practical method for field diagnosis of swine diseases. Am J Vet Med 14: 468-470.

Krammer F, García-Sastre A, Palese P. 2017. Is it possible to develop a "universal" influenza virus vaccine? Toward a universal influenza virus vaccine: potential target antigens and critical aspects for vaccine development. Cold Spring Harb Perspect Biol 10: a028845.

Kuiken T, Taubenberger JK. 2008. The pathology of human influenza revisited. Vaccine 26: D59-D66. doi:10.1016/j .vaccine.2008.07.025
LeCount ER. 1919a. Disseminated necrosis of the pulmonary capillaries in influenzal pneumonia. J Am Med Assoc 72: 1519-1520. doi:10.1001/jama.1919.02610210015003

LeCount ER. 1919b. The pathologic anatomy of influenzal bronchopneumonia. J Am Med Assoc 72: 650-652. doi: 10 $.1001 /$ jama.1919.02610090034009

Lubinski H. 1923. Grippepandemie in Breslau 1918-22. Zentralblatt für Bakteriologie, Parasitenkunde und Infektionskrankheiten 91: 372-383.

Ma W, Lager KM, Li X, Janke BH, Mosier DA, Painter LE, Ulery ES, Ma J, Lekcharoensuk P, Webby RJ, et al. 2011. Pathogenicity of swine influenza viruses possessing an avian or swine-origin PB2 polymerase gene evaluated in mouse and pig models. Virology 410: 1-6. doi:10.1016/j .virol.2010.10.027

Mamelund SE. 2006. A socially neutral disease? Individual social class, household wealth and mortality from Spanish influenza in two socially contrasting parishes in Kristiania 1918-19. Soc Sci Med 62: 923-940. doi:10.1016/j .socscimed.2005.06.051

Manz B, Schwemmle M, Brunotte L. 2013. Adaptation of avian influenza A virus polymerase in mammals to overcome the host species barrier. J Virol 87: 7200-7209. doi:10.1128/JVI.00980-13

Masurel N. 1976. Swine influenza virus and the recycling of influenza-A viruses in man. Lancet 308: 244-247. doi:10 .1016/S0140-6736(76)91038-2

Mehle A, Doudna JA. 2009. Adaptive strategies of the influenza virus polymerase for replication in humans. Proc Natl Acad Sci 106: 21312-21316. doi:10.1073/pnas .0911915106

Memoli MJ, Tumpey TM, Jagger BW, Dugan VG, Sheng ZM, Qi L, Kash JC, Taubenberger JK. 2009. An early "classical" swine H1N1 influenza virus shows similar pathogenicity to the 1918 pandemic virus in ferrets and mice. Virology 393: 338-345. doi:10.1016/j.virol.2009.08 .021

Morens DM, Taubenberger JK. 2009. Understanding influenza backward. JAMA 302: 679-680. doi:10.1001/jama .2009 .1127

Morens DM, Taubenberger JK. 2010. Historical thoughts on influenza viral ecosystems, or behold a pale horse, dead dogs, failing fowl, and sick swine. Influenza Other Respir Viruses 4: 327-337. doi:10.1111/j.1750-2659.2010 .00148.x

Morens DM, Taubenberger JK. 2011. Pandemic influenza: certain uncertainties. Rev Med Virol 21: 262-284.

Morens DM, Taubenberger JK. 2018. The mother of all pandemics is 100 years old (and going strong)! Am J Public Health 108: 1449-1454.

Morens DM, Taubenberger JK, Fauci AS. 2008. Predominant role of bacterial pneumonia as a cause of death in pandemic influenza: implications for pandemic influenza preparedness. J Infect Dis 198: 962-970. doi:10.1086/ 591708

Morens DM, Taubenberger JK, Fauci AS. 2009. The persistent legacy of the 1918 influenza virus. N Engl J Med 361: 225-229. doi:10.1056/NEJMp0904819

Morens DM, Taubenberger JK, Folkers GK, Fauci AS. 2010. Pandemic influenza's 500th anniversary. Clin Infect Dis 51: 1442-1444. doi:10.1086/657429 
J.K. Taubenberger and D.M. Morens

Morens DM, Subbarao K, Taubenberger JK. 2012. Engineering $\mathrm{H} 5 \mathrm{~N} 1$ avian influenza viruses to study human adaptation. Nature 486: 335-340. doi:10.1038/nature11170

Morens DM, Taubenberger JK, Fauci AS. 2013a. H7N9 avian influenza $A$ virus and the perpetual challenge of potential human pandemicity. mBio 4: e00445. doi:10.1128/mBio .00445-13

Morens DM, Taubenberger JK, Fauci AS. 2013b. Pandemic influenza viruses-hoping for the road not taken. N Engl J Med 368: 2345-2348. doi:10.1056/NEJMp1307009

Mulder J, Hers JFP. 1972. Influenza. Wolters-Noordhoff, Groningen, Germany.

Nabel GJ, Fauci AS. 2010. Induction of unnatural immunity: prospects for a broadly protective universal influenza vaccine. Nat Med 16: 1389-1391. doi:10.1038/nm1210-1389

Nakajima K, Desselberger U, Palese P. 1978. Recent human influenza $\mathrm{A}(\mathrm{H} 1 \mathrm{~N} 1)$ viruses are closely related genetically to strains isolated in 1950. Nature 274: 334-339. doi:10 $.1038 / 274334 \mathrm{a} 0$

Nelson MI, Viboud C, Vincent AL, Culhane MR, Detmer SE, Wentworth DE, Rambaut A, Suchard MA, Holmes EC, Lemey P. 2015. Global migration of influenza A viruses in swine. Nat Commun 6: 6696. doi:10.1038/ncomms7696

Neumann G, Watanabe T, Ito H, Watanabe S, Goto H, Gao P, Hughes M, Perez DR, Donis R, Hoffmann E, et al. 1999 Generation of influenza A viruses entirely from cloned cDNAs. Proc Natl Acad Sci 96: 9345-9350. doi:10.1073/ pnas.96.16.9345

Oxford JS. 2000. Influenza A pandemics of the 20th century with special reference to 1918: virology, pathology and epidemiology. Rev Med Virol 10: 119-133. doi:10.1002/ (SICI)1099-1654(200003/04)10:2<119::AID-RMV272>3 .0.CO;2-O

Oxford JS, Sefton A, Jackson R, Innes W, Daniels RS, Johnson NP. 2002. World War I may have allowed the emergence of "Spanish" influenza. Lancet Infect Dis 2: 111114. doi:10.1016/S1473-3099(02)00185-8

Ozberk V, Pandey M, Good MF. 2018. Contribution of cryptic epitopes in designing a group A Streptococcal vaccine. Hum Vaccin Immunother 14: 2034-2052. doi:10.1080/ 21645515.2018.1462427

Palese P, Tumpey TM, García-Sastre A. 2006. What can we learn from reconstructing the extinct 1918 pandemic in fluenza virus? Immunity 24: 121-124. doi:10.1016/j .immuni.2006.01.007

Park JK, Taubenberger JK. 2016. Universal influenza vaccines: to dream the possible dream? ACS Infect Dis 2: 57. doi:10.1021/acsinfecdis.5b00146

Perrone LA, Plowden JK, García-Sastre A, Katz JM, Tumpey TM. 2008. H5N1 and 1918 pandemic influenza virus infection results in early and excessive infiltration of macrophages and neutrophils in the lungs of mice. PLoS Pathog 4: e1000115. doi:10.1371/journal.ppat.1000115

Philip RN, Lackman DB. 1962. Observations on the present distribution of influenza $\mathrm{A} /$ swine antibodies among Alaskan natives relative to the occurrence of influenza in 1918-1919. Am J Hyg 75: 322-334.

Qi L, Kash JC, Dugan VG, Wang R, Jin G, Cunningham RE, Taubenberger JK. 2009. Role of sialic acid binding specificity of the 1918 influenza virus hemagglutinin protein in virulence and pathogenesis for mice. J Virol 83: 3754 3761. doi:10.1128/JVI.02596-08

Qi L, Kash JC, Dugan VG, Jagger BW, Lau YF, Sheng ZM, Crouch EC, Hartshorn KL, Taubenberger JK. 2011. The ability of pandemic influenza virus hemagglutinins to induce lower respiratory pathology is associated with decreased surfactant protein D binding. Virology 412: 426434. doi:10.1016/j.virol.2011.01.029

Qi L, Davis AS, Jagger BW, Schwartzman LM, Dunham EJ, Kash JC, Taubenberger JK. 2012. Analysis by single-gene reassortment demonstrates that the 1918 influenza virus is functionally compatible with a low-pathogenicity avian influenza virus in mice. J Virol 86: 9211-9220. doi:10 .1128/JVI.00887-12

Qi L, Pujanauski LM, Davis AS, Schwartzman LM, Chertow DS, Baxter D, Scherler K, Hartshorn KL, Slemons RD, Walters KA, et al. 2014. Contemporary avian influenza A virus subtype $\mathrm{H1}, \mathrm{H} 6, \mathrm{H} 7, \mathrm{H} 10$, and $\mathrm{H} 15$ hemagglutinin genes encode a mammalian virulence factor similar to the 1918 pandemic virus $\mathrm{H} 1$ hemagglutinin. mBio 5: e02116.

Rabadan R, Levine AJ, Robins H. 2006. Comparison of avian and human influenza A viruses reveals a mutational bias on the viral genomes. J Virol 80: 11887-11891. doi:10 .1128/JVI.01414-06

Reid AH, Fanning TG, Hultin JV, Taubenberger JK. 1999. Origin and evolution of the 1918 "Spanish" influenza virus hemagglutinin gene. Proc Natl Acad Sci 96: 16511656. doi:10.1073/pnas.96.4.1651

Reid AH, Fanning TG, Janczewski TA, Taubenberger JK. 2000. Characterization of the 1918 "Spanish" influenza virus neuraminidase gene. Proc Natl Acad Sci 97: 67856790. doi:10.1073/pnas.100140097

Reid AH, Fanning TG, Janczewski TA, McCall S, Taubenberger JK. 2002. Characterization of the 1918 "Spanish" influenza virus matrix gene segment. J Virol 76: 1071710723. doi:10.1128/JVI.76.21.10717-10723.2002

Reid AH, Janczewski TA, Lourens RM, Elliot AJ, Daniels RS, Berry CL, Oxford JS, Taubenberger JK. 2003. 1918 influenza pandemic caused by highly conserved viruses with two receptor-binding variants. Emerg Infect Dis 9: 12491253. doi:10.3201/eid0910.020789

Reid AH, Taubenberger JK, Fanning TG. 2004a. Evidence of an absence: the genetic origins of the 1918 pandemic influenza virus. Nat Rev Microbiol 2: 909-914. doi:10 $.1038 /$ nrmicro1027

Reid AH, Fanning TG, Janczewski TA, Lourens RM, Taubenberger JK. 2004b. Novel origin of the 1918 pandemic influenza virus nucleoprotein gene. J Virol 78: 12462 12470. doi:10.1128/JVI.78.22.12462-12470.2004

Scholtissek C, Rohde W, Von Hoyningen V, Rott R. 1978. On the origin of the human influenza virus subtypes $\mathrm{H} 2 \mathrm{~N} 2$ and H3N2. Virology 87: 13-20. doi:10.1016/0042-6822 (78)90153-8

Sheng ZM, Chertow DS, Ambroggio X, McCall S, Przygodzki RM, Cunningham RE, Maximova OA, Kash JC Morens DM, Taubenberger JK. 2011. Autopsy series of 68 cases dying before and during the 1918 influenza pandemic peak. Proc Natl Acad Sci 108: 16416-16421. doi:10 $.1073 /$ pnas. 1111179108

Shope RE. 1931. Swine influenza. I: Experimental transmission and pathology. J Exp Med 54: 349-359. doi:10.1084/ jem.54.3.349 
Shope RE. 1936. The incidence of neutralizing antibodies for swine influenza virus in the sera of human beings of different ages. J Exp Med 63: 669-684. doi:10.1084/jem.63.5 .669

Shortridge KF. 1999. The 1918 "Spanish" flu: pearls from swine? Nat Med 5: 384-385. doi:10.1038/7383

Smith W, Andrewes C, Laidlaw P. 1933. A virus obtained from influenza patients. Lancet 222: 66-68. doi:10.1016/ S0140-6736(00)78541-2

Smith GJ, Bahl J, Vijaykrishna D, Zhang J, Poon LL, Chen H, Webster RG, Peiris JS, Guan Y. 2009. Dating the emergence of pandemic influenza viruses. Proc Natl Acad Sci 106: 11709-11712. doi:10.1073/pnas.0904991106

Stevens J, Corper AL, Basler CF, Taubenberger JK, Palese P, Wilson IA. 2004. Structure of the uncleaved human H1 hemagglutinin from the extinct 1918 influenza virus. Science 303: 1866-1870. doi:10.1126/science.1093373

Stevens J, Blixt O, Glaser L, Taubenberger JK, Palese P, Paulson JC, Wilson IA. 2006. Glycan microarray analysis of the hemagglutinins from modern and pandemic influenza viruses reveals different receptor specificities. J Mol Biol 355: 1143-1155. doi:10.1016/j.jmb.2005.11.002

Subbarao EK, London W, Murphy BR. 1993. A single amino acid in the PB2 gene of influenza A virus is a determinant of host range. J Virol 67: 1761-1764.

Taubenberger JK, Kash JC. 2010. Influenza virus evolution, host adaptation, and pandemic formation. Cell Host Microbe 7: 440-451. doi:10.1016/j.chom.2010.05.009

Taubenberger JK, Morens DM. 2006. 1918 Influenza: the mother of all pandemics. Emerg Infect Dis 12: 15-22. doi:10.3201/eid1209.05-0979

Taubenberger JK, Morens DM. 2008. The pathology of influenza virus infections. Annu Rev Pathol 3: 499-522. doi:10.1146/annurev.pathmechdis.3.121806.154316

Taubenberger JK, Morens DM. 2009. Pandemic influenzaincluding a risk assessment of H5N1. Rev Sci Tech 28: 187-202. doi:10.20506/rst.28.1.1879

Taubenberger JK, Morens DM. 2013. Influenza viruses: breaking all the rules. mBio 4: e00365.

Taubenberger JK, Reid AH, Krafft AE, Bijwaard KE, Fanning TG. 1997. Initial genetic characterization of the 1918 "Spanish" influenza virus. Science 275: 1793-1796. doi:10.1126/science.275.5307.1793

Taubenberger JK, Reid AH, Janczewski TA, Fanning TG. 2001. Integrating historical, clinical and molecular genetic data in order to explain the origin and virulence of the 1918 Spanish influenza virus. Philos Trans $R$ Soc Lond B Biol Sci 356: 1829-1839. doi:10.1098/rstb.2001 .1020

Taubenberger JK, Reid AH, Lourens RM, Wang R, Jin G, Fanning TG. 2005. Characterization of the 1918 influenza virus polymerase genes. Nature 437: 889-893. doi:10 $.1038 /$ nature 04230

Taubenberger JK, Hultin JV, Morens DM. 2007. Discovery and characterization of the 1918 pandemic influenza virus in historical context. Antivir Ther 12: 581-591.

Taubenberger JK, Kash JC, Morens DM. 2019. The 1918 influenza pandemic: 100 years of questions answered and unanswered. Sci Transl Med 11: eaau5485. doi:10 $.1126 /$ scitranslmed.aau5485
Thompson WW, Shay DK, Weintraub E, Brammer L, Cox N, Anderson LJ, Fukuda K. 2003. Mortality associated with influenza and respiratory syncytial virus in the United States. JAMA 289: 179-186. doi:10.1001/jama .289.2.179

Tumpey TM, García-Sastre A, Mikulasova A, Taubenberger JK, Swayne DE, Palese P, Basler CF. 2002. Existing antivirals are effective against influenza viruses with genes from the 1918 pandemic virus. Proc Natl Acad Sci 99: 13849-13854. doi:10.1073/pnas.212519699

Tumpey TM, García-Sastre A, Taubenberger JK, Palese P, Swayne DE, Basler CF. 2004. Pathogenicity and immunogenicity of influenza viruses with genes from the 1918 pandemic virus. Proc Natl Acad Sci 101: 3166-3171. doi:10.1073/pnas.0308391100

Tumpey TM, Basler CF, Aguilar PV, Zeng H, Solórzano A, Swayne DE, Cox NJ, Katz JM, Taubenberger JK, Palese P, et al. 2005a. Characterization of the reconstructed 1918 Spanish influenza pandemic virus. Science 310: 77-80. doi:10.1126/science.1119392

Tumpey TM, García-Sastre A, Taubenberger JK, Palese P, Swayne DE, Pantin-Jackwood MJ, Schultz-Cherry S, Solórzano A, Van Rooijen N, Katz JM, et al. 2005b. Pathogenicity of influenza viruses with genes from the 1918 pandemic virus: functional roles of alveolar macrophages and neutrophils in limiting virus replication and mortality in mice. J Virol 79: 14933-14944. doi:10.1128/JVI.79 .23.14933-14944.2005

Tumpey TM, Maines TR, Van Hoeven N, Glaser L, Solórzano A, Pappas C, Cox NJ, Swayne DE, Palese P, Katz JM, et al. 2007. A two-amino acid change in the hemagglutinin of the 1918 influenza virus abolishes transmission. Science 315: 655-659. doi:10.1126/science. 1136212

Viboud C, Eisenstein J, Reid AH, Janczewski TA, Morens DM, Taubenberger JK. 2013. Age- and sex-specific mortality associated with the 1918-1919 influenza pandemic in Kentucky. J Infect Dis 207: 721-729. doi:10.1093/in fdis/jis745

Vukotich CJ Jr, Coulborn RM, Aragon TJ, Baker MG, Burrus BB, Aiello AE, Cowling BJ, Duncan A, Enanoria W, Fabian MP, et al. 2010. Findings, gaps, and future direction for research in nonpharmaceutical interventions for pandemic influenza. Emerg Infect Dis 16: e2. doi:10.3201/ eid1604.090719

Walia RR, Anderson TK, Vincent AL. 2019. Regional patterns of genetic diversity in swine influenza A viruses in the United States from 2010 to 2016. Influenza Other Respir Viruses 13: 262-273. doi:10.1111/irv.12559

Walters KA, D’Agnillo F, Sheng ZM, Kindrachuk J, Schwartzman LM, Kuestner RE, Chertow DS, Golding BT, Taubenberger JK, Kash JC. 2016. 1918 pandemic influenza virus and Streptococcus pneumoniae co-infection results in activation of coagulation and widespread pulmonary thrombosis in mice and humans. J Pathol 238: 85-97. doi:10.1002/path.4638

Watanabe T, Watanabe S, Shinya K, Kim JH, Hatta M, Kawaoka Y. 2009. Viral RNA polymerase complex promotes optimal growth of 1918 virus in the lower respiratory tract of ferrets. Proc Natl Acad Sci 106: 588-592. doi:10.1073/ pnas.0806959106

Watanabe T, Zhong G, Russell CA, Nakajima N, Hatta M, Hanson A, McBride R, Burke DF, Takahashi K, Fukuya- 
J.K. Taubenberger and D.M. Morens

ma S, et al. 2014. Circulating avian influenza viruses closely related to the 1918 virus have pandemic potential. Cell Host Microbe 15: 692-705. doi:10.1016/j.chom.2014.05 .006

Winternitz MC, Wason IM, McNamara FP. 1920. The pathology of influenza. Yale University Press, New Haven, CT.

Worobey M, Han GZ, Rambaut A. 2014. Genesis and pathogenesis of the 1918 pandemic H1N1 influenza A virus. Proc Natl Acad Sci 111: 8107-8112. doi:10.1073/pnas .1324197111
Xiao YL, Kash JC, Beres SB, Sheng ZM, Musser JM, Taubenberger JK. 2013. High-throughput RNA sequencing of a formalin-fixed, paraffin-embedded autopsy lung tissue sample from the 1918 influenza pandemic. J Pathol 229: 535-545. doi:10.1002/path.4145

Yamada S, Hatta M, Staker BL, Watanabe S, Imai M, Shinya K, Sakai-Tagawa Y, Ito M, Ozawa M, Watanabe T, et al. 2010. Biological and structural characterization of a host-adapting amino acid in influenza virus. PLoS Pathog 6: e1001034. doi:10.1371/journal.ppat .1001034 


\section{$\&_{\mathrm{CSH}}^{\infty} \&$ Cold Spring Harbor

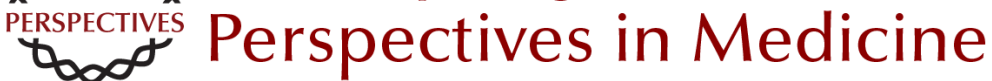

\section{The 1918 Influenza Pandemic and Its Legacy}

Jeffery K. Taubenberger and David M. Morens

Cold Spring Harb Perspect Med 2020; doi: 10.1101/cshperspect.a038695 originally published online December 23, 2019

\section{Subject Collection Influenza: The Cutting Edge}

\section{Emerging HxNy Influenza A Viruses} William J. Liu, Yan Wu, Yuhai Bi, et al.

Equine Influenza

Thomas M. Chambers

\section{Human Influenza Epidemiology \\ Sukhyun Ryu and Benjamin J. Cowling}

Host Cell Factors That Interact with Influenza

Virus Ribonucleoproteins

Ecco Staller and Wendy S. Barclay

Induction and Evasion of Type-I Interferon

Responses during Influenza A Virus Infection

Raquel Muñoz-Moreno, Carles Martínez-Romero and Adolfo García-Sastre

Structure and Function of Influenza Polymerase Joanna M. Wandzik, Tomas Kouba and Stephen Cusack

H7N9 Influenza Virus in China Chengjun Li and Hualan Chen

H5 Influenza Viruses in Egypt Rabeh El-Shesheny, Ahmed Kandeil, Ahmed Mostafa, et al.
Antivirals Targeting the Neuraminidase Larisa Gubareva and Teena Mohan

Accessory Gene Products of Influenza A Virus Rute M. Pinto, Samantha Lycett, Eleanor Gaunt, et al.

Influenza Immunization in the Context of

Preexisting Immunity Susanne L. Linderman, Ali H. Ellebedy, Carl Davis, et al.

Hemagglutinin Structure and Activities Steven J. Gamblin, Sébastien G. Vachieri, Xiaoli Xiong, et al.

Live Attenuated Cold-Adapted Influenza Vaccines Kanta Subbarao

Next-Generation Influenza Vaccines Masaru Kanekiyo and Barney S. Graham

Selective Genome Packaging Mechanisms of Influenza A Viruses Takeshi Noda

Systems Biological Analysis of Immune Response to Influenza Vaccination Mario Cortese, Amy C. Sherman, Nadine G. Rouphael, et al.

For additional articles in this collection, see http://perspectivesinmedicine.cshlp.org/cgi/collection/ 